\title{
The Future of the American Law School or, How the 'Crits' Led Brian Tamanaha Astray and His Failing Law Schools Fails
}

Stephen F. Diamond

Santa Clara University School of Law, sdiamond@scu.edu

Follow this and additional works at: http://digitalcommons.law.scu.edu/facpubs

Part of the Law Commons

\section{Automated Citation}

Stephen F. Diamond, The Future of the American Law School or, How the 'Crits' Led Brian Tamanaha Astray and His Failing Law Schools Fails (2013),

Available at: http://digitalcommons.law.scu.edu/facpubs/610 
The future of the American law school or, how the "Crits" led Brian Tamanaha astray and his Failing Law Schools fails

Stephen F. Diamond

Santa Clara University School of Law

January 27, 2013

Contact: sdiamond@scu.edu 


\begin{abstract}
Debate over the impact of the economic crisis on the future of the American law school has reached an exceptional level of intensity. Brian Tamanaha's short book, Failing Law Schools, serves as the manifesto for those who believe the law school must undergo radical restructuring and cost cutting. While there is room for disagreement with almost all aspects of the reform argument no critic of Tamanaha has attempted to place his critique in the context of his pre-existing scholarly work on the rule of law. This review essay argues that only an appreciation for the dual nature of the modern rule of law allows us to explain what is happening to the American law school and to see clearly the limitations of the critics' arguments. The essay suggests that diversity within a tenure based academic model is a valuable characteristic of the current model that must be preserved.
\end{abstract}




\section{Introduction}

The law school is a "scam" argument that has taken hold in the minds of many understandably angry and disappointed jobless or underemployed law school graduates recently depends largely on some tendentious ideas. The intensity with which some in this group profess their views reminds one of the various "truther" movements that now spring up in the wake of traumatic events such as 9/11 or Sandy Hook. ${ }^{1}$ A "scam" implies, of course, that law schools take people's money and leave them with nothing. It is a serious charge. It is, in my view, unsustainable. It appears to depend on the non sequitur that law schools bore responsibility for the sudden and unpredictable collapse in the job market in post-2008 period. But there is no disclosure language or data that could have been provided to law students in, for example, 2006 that would have allowed students to plan for the waterfall towards which they were headed.

So if it is readily obvious that the "scam" claim has no objective basis, how did this tense and even ugly ${ }^{2}$ situation develop? Some say it began with Washington University School of Law Professor Brian Tamanaha's bracing call for change on the

\footnotetext{
${ }^{1}$ One readily available test of the lack of rationality of the "scam" idea is to take notice of its supporters' apparent disinterest in concrete proposals for debt relief and other forms of assistance available to law school graduates caught in the economic downturn.

2 A few minutes on "Inside the Law School Scam," the website run by Paul Campos and Deborah Merritt, two tenured law professors and thus presumably themselves beneficiaries of the scam, will serve to convince. Campos and Merritt pose as traitors to the carney clan that they came from, now willing to reveal what was behind the curtain. Merritt has taken her extra-academic activities one step further and is involved in a new joint venture with Kyle McEntee, the founder of another center of the truther milieu, Law School Transparency, Inc. (LST). LST offers what it claims is previously unavailable data regarding the troubled state of American law schools. LST is an early stage startup seeking, as McEntee explained to the ABA recently, $\$ 500,000$ in angel funding to promote LST's data base products.
} 
“Balkinization" blog in the summer of 2010. ${ }^{3}$ Let's examine that and see if we can sort all this out.

\section{The Tamanaha Manifesto and the Rule of Law Debate}

In his manifesto for the reform movement, Failing Law Schools, Tamanaha describes in absorbing detail many of the shortcomings of American law schools, without a great deal of attention to the important accomplishments of the institution unfortunately (including, it should be said, Tamanaha's own work on the rule of law) ${ }^{4}$ He might even be our Kingsley Amis absent, sadly, the brilliant satire. ${ }^{5}$ But Tamanaha relies on very generalized data sets that do not provide persuasive evidence of misbehavior by any individual school, fails to test for counter-factual explanations, and draws conclusions that are only one among several possible explanations for the current situation.

In light of Tamanaha's own conservative perspective on legal theory - one that I disagree with but view as articulate and informative - one consideration is that there is an ideological agenda at work here. A reshaping of American law schools along the lines suggested by his book would do a great service to American capital, which despises in many ways the legal profession and even the rule of law as it has evolved since the New Deal. Under tremendous economic pressure today, on a global scale

${ }^{3}$ Brian Tamanaha, "Wake up, fellow law professors, to the casualties of our enterprise," Jun. 13, 2010, available at http:/ / balkin.blogspot.com/2010/06/wake-up-fellow-law-professors-to.html.

4 Brian Z. Tamanaha, Failing Law Schools (2012).

${ }^{5}$ See Kingsley Amis, Lucky Jim (1954). One might be tempted to read his book, as a whole, as satire but that is giving the very earnest Tamanaha too much credit. 
capital is looking for ways to cut costs, particularly legal costs. ${ }^{6}$ Austerity is the order of the day from Detroit to D.C. to Athens. A successful assault on what are viewed as costly and entrenched law schools would help tremendously in the battle against law firms and the courts as a whole.

Why might Tamanaha be willing to aid in this fight? It is not necessarily the case that he would do so with intent, though I do not rule that out. ${ }^{7}$ Among many other issues, Tamanaha's work on the rule of law considers carefully the relationship between property rights and the state. That is a traditional concern of conservative figures like Hayek and Mises, whom Tamanaha clearly admires and whose work he writes about at length. But a problem with this approach is that those figures never dealt adequately with the impact of the transition by the 1930s from property to capital. The end of the Lochner-induced laissez-faire era produced a traumatic ideological crisis within classical American liberal thought (what many now think of as conservatism).

Why, exactly? Because when property becomes capital, that is, when the accumulation of sufficient wealth enables a property owner to employ living labor to produce surplus value, two souls in the rule of law emerge. One guards narrow conceptions of property rights against intrusion from the state, what might be called the classical concept of the rule of law. The other soul that emerges, however, is a social

${ }^{6}$ Igor Greenwald, Is Capitalism Dying? Forbes.com, Jan. 7, 2013 available at http://www.forbes.com/sites/igorgreenwald/2013/01/07/is-capitalism-dying/; and Citi Private Bank and Hildebrandt Consulting, 2013 Client Advisory, available at http://online.wsj.com/public/resources/documents/CitiHildebrandt2013ClientAdvisory.pdf.

${ }^{7}$ One opportunity to explore this possibility has been lost. Tamanaha cancelled a long planned visit to present his work at my law school this spring soon after an earlier version of this review was posted on my blog, www.stephen-diamond.com. The intensely hostile reaction to that and several other posts on the "scam" issue forced me to close down the blog for a period of time. 
concept of the rule of law that guards the human rights of labor against intrusion by capital and its allies in the deteriorating aristocratic classes, if we are talking of Europe and England, and its allies in the new managerial state if we are talking about the New Deal United States. ${ }^{8}$

But for today's conservatives this second soul of the rule of law, one that guards social rights against the encroachments of both capital and the state, to the extent it is even partially acknowledged to exist, is a form of legal pathology. Union busting that would return us to the world of "Say's Law," where there are no impediments (or "frictions") such as trade unions to the ruthless destruction of wages and jobs, is the order of the day. Tamanaha takes an axe to the world of law schools with an argument that echoes these kinds of reactionary calls to smash organized labor. ${ }^{9}$ And thus it is not a surprise that Walter Olson of the Cato Institute introduced Tamanaha as the "good cop" of the movement when he appeared with its "bad cop," Paul Campos of the University of Colorado, at the anti-union Koch Brothers' funded entity recently. Tamanaha's misstep in this setting is that he promotes a unitary view of the rule of law rather than explicating its two souls. This is most clear in his brief but admirable

\footnotetext{
${ }^{8}$ An excellent introduction to one example of the social concept can be found in the work of Katherine Stone of UCLA on industrial pluralism, which represented the creation of a social rule of law in the workplace. See "The Post-War Paradigm in American Labor Law," 90 Yale L.J. 1509 (1981). I relied on similar arguments "The PetroChina Syndrome: Regulating Capital Markets in the Anti-Globalization Era," 29 J. Corp. L. 39 (2003).

9 The lawyer Raoul Felder made this analogy explicit in a letter to the New York Times endorsing the reformers' cause. Letter, N.Y. Times, Jan. 25, 2013 ("Frankly, law school is a waste of money for the students and their parents, and is best equated to the price one must pay to belong to a union.") Available at http:// www.nytimes.com/2013/01/26/opinion/how-much-law-school-is-enough.html?_r=0.
} 
treatment in On The Rule of $\mathrm{Law}^{10}$ of the important statements about the rule of law by the late British Marxist and historian E.P. Thompson. Tamanaha paints Thompson as an outlier on the left because of the hostile reception of his work by what Tamanaha calls the "far left." By that he means Morton Horwitz, above all, who attacked Thompson in a famous book review.11 But Horwitz, of course, is hardly a representative figure of the left. He is representative of the "critical legal studies" movement (CLS, or, simply, the "Crits"), of course, and they are, in turn, one offshoot of an authoritarian strand within New Left era thinking.

But as I exhaustively explore in numerous posts on my blog and elsewhere no one should mistake the authoritarian left for the left as a whole. ${ }^{12}$ Thompson, in fact, was representative of, and played a leading role in, creating the anti-authoritarian left of the late 20th century. This left, not the caricature left of the Crits that appears in Tamanaha's work, played an important role in, among other situations, the success of Polish Solidarity, the rise of a new labor movement in China and in less visible forms in the overthrow of Latin American dictatorships as well as South African apartheid. Thompson personally was a leader of the very important European Nuclear Disarmament Movement (END) in the 1980s, which established exceptional

\footnotetext{
${ }^{10}$ Brian Z. Tamanaha, On the Rule of Law: History, Politics, Theory (2004).

11 Morton J. Horwitz, “The Rule of Law: An Unqualified Human Good?” Yale Law Journal 86 (1976-77): 561-66, reviewing Douglas Hay, Peter Linebaugh, John G. Rule, E. P. Thompson, and Cal Winslow, Albion's Fatal Tree: Crime and Society in Eighteenth- Century England (New York: Pantheon Books, 1975) and E. P. Thompson, Whigs and Hunters: The Origin of the Black Act (New York: Pantheon Books, 1975) ("...I do not see how a Man of the Left can describe the rule of law as 'an unqualified human good'!")

12 See, for example, my From "Che" to China: Labor and Authoritarianism in the New Global Economy (2009) and Rights and Revolution: The Rise and Fall of Nicaragua's Sandinista Movement (2013).
} 
relationships with movements like Charter 77 across the Iron Curtain that stood together against the militarization of Europe by both Washington and Moscow.

In my view Thompson's work - as a whole, not just his essay on the rule of law can only be understood fully if situated within the context of this real world movement of democratic social power. This movement is one that can trace itself back to the era of the Black Act that set the stage for Thompson's assessment of the rule of law but which takes on greater import in the era of capital. ${ }^{13}$ One of its goals is the emergence of a social (though not quite socialist) soul within the rule of law.

With only the traditional unitary theory of the rule of law to work with, however, Tamanaha is less well equipped to deal with the complexities of the era of property as capital, of power that is defined by class conflict over the production of surplus value as well as by the state. It is possible then that this approach creates a kind of intellectual blind spot that may have allowed him to go down the path he has taken.

For the modern law school is in itself a microcosm of this same socio-economic problematic and to ignore the dualistic nature of the rule of law is to misunderstand the important contribution of the law school itself to the rule of law. As the Appellate Division of the New York Supreme Court, quoting in part Felix Frankfurter, recalled very recently when dismissing the central claim of the law school is a "scam" milieu, charges of employment statistics fraud, against New York Law School:

We are not unsympathetic to plaintiffs' concerns. We recognize that students may be susceptible to misrepresentations by law school. As such, ' $[\mathrm{t}]$ his Court does not necessarily agree [with Supreme Court] that [all] college graduates are

${ }^{13}$ E.P. Thompson, Whigs and hunters: The origin of the Black Act (1975). 
particularly sophisticated in making career or business decisions'....As a result, they sometimes make decisions to yoke themselves and their spouses and/or their children to a crushing burden because the schools have made misleading representations that give the impression that a full time job is easily obtainable when in fact it is not.

Given this reality, it is important to remember that the practice of law is a noble profession that takes pride in its high ethical standards. Indeed, in order to join and continue to enjoy the privilege of being an active member of the legal profession, every prospective and active member of the profession is called upon to demonstrate candor and honesty. This requirement is not a trivial one. For the profession to continue to ensure that its members remain candid and honest public servants, all segments of the profession must work in concert to instill the importance of those values. 'In the last analysis, the law is what the lawyers are. And the law and the lawyers are what the law schools make them. ${ }^{14}$...Defendant and its peers owe prospective students more than just barebones compliance with their legal obligations. Defendant and its peers are educational not-for-profit institutions. They should be dedicated to advancing the public welfare. In that vein, defendant and its peers have at least an ethical obligation of absolute candor to their prospective students." 15

(Bold italics added; Normal italics in original) Thus, the Court was suggesting that while there was no actionable fraud at work in the kinds of marketing materials used by the law school, any step over that line would have serious consequences.

Given the critical role of the law school in shaping the law it is not inappropriate to appropriate E.P. Thompson's felicitous comment about the "rule of law" and suggest that the modern law school itself, in its commitment to teaching and research like the university of which it is an integral part, is an "unqualified human good" that must be

\footnotetext{
14 Letter from Felix Frankfurter, Professor, Harvard Law School, to Mr. Rosenwald 3 (May 13, 1927) (Felix Frankfurter papers, Harvard Law School library), quoted in Rand Jack, Dana C. Jack, Moral Vision and Professional Decisions: The Changing Values of Women and Men Lawyers 156 (1989).

15 Gomez-Jimenez v. New York Law Sch., 2012 NY Slip Op. 08819, Dec. 20, 2012, available at http://www.nycourts.gov/reporter/3dseries/2012/2012_08819.htm. My guess is that absent actual fraud other courts in actions of this nature will follow the lead of this opinion. But law schools and law professors must absorb the import of those last two paragraphs in the opinion.
} 
defended even if the school must constantly consider reforms in response to inevitable external change.

Over the last few decades the law school has been the situs of vigorous intellectual battles and power struggles that reflect competing views of the nature of law and of the rule of law. It is the system of tenure, academic freedom and shared governance among faculty, deans, trustees and other constituencies that creates and protects the vital intellectual space that is the modern law school and thus allows such battles to take place. It may be true, as Henry Kissinger is alleged to have said, that the reason battles in faculty meetings are so intense is that there is so little to fight over. Nonetheless, that does not mean there are not important conflicts underway.

Far from producing a homogenous environment, this system encourages the pursuit and teaching of knowledge and has, over the last few decades, caused the law school to flourish in diversity of ideas and approaches. The "unitary" model that Tamanaha decries is a thing of the past, attacked by the profession itself expressly in the 1971 Carrington Report, 16 and now a dead letter. It was indeed the case that the Langdellian model imposed a kind of rigidity on the law school that controlled access of new ideas and new kinds of students, consistent perhaps with similar trends in other parts of American society in the mid-20th century.

But the influx of women and minorities, the genuine attempt of law schools to encourage the kinds of research and creativity found in other parts of the campus, the

\footnotetext{
${ }^{16}$ Curriculum Study Committee, Association Of American Law Schools, Training For The Public Professions Of The Law: 1971. Part One. Section II, Proceedings, Association Of American Law Schools, 1971 Annual Meeting, Reprinted In Herbert L. Packer And Thomas Ehrlich, New Directions In Legal Education 93-329 (1972).
} 
forces of globalization and the restructuring of the economy as it moved towards a new era of technology-led innovation have all combined to create a very different culture in American law schools. Tamanaha himself may have been scarred by the experience he encountered in his first academic position at St. John's University where it appears the school had entombed itself in a kind of cocoon, most likely a defense against the very change occurring all around it. But that is hardly a universal experience. Thus, in the end, Tamanaha's sympathy for the pre-Langdellian period, or, more accurately, the preRoot report days, ${ }^{17}$ is a straw man predictably ripe for knocking down.

Thus, Tamanaha's proposal to allow law schools to "differentiate," invoking expressly the approach of century old defender of the two-tier law school structure Adolf Z. Reed, ${ }^{18}$ is a reactionary proposal and must be scrutinized for its likely inevitable impact on tenure and academic freedom. Such a model would allow new schools to develop that are called "teaching schools" but would be in fact what used to be called "diploma mills." It would pressure lower ranked schools already in existence,

\footnotetext{
17 "A year before publication of the Reed Report [see note 18], the ABA's Section of Legal Education and Admissions to the Bar, prodded by legal academics, created a Special Committee on Legal Education." "That committee, called the Root Committee after its chairman, Elihu Root, rejected the idea of a differentiated bar." Michael Ariens, Law School Branding and the Future of Legal Education, 34 ST. MARY'S L.J. 301, 310 (2003) (citing Proceedings of the Section of Legal Education and Admissions to the Bar, 45 ABA Rep. 465, 465-66 (1920) (reporting on the formation of the committee and election of members to serve on the committee)) (citing Report of the Special Committee to the Section of Legal Education and Admissions to the Bar of the American Bar Association, 46 ABA Rep. 679, 681-83 (1921) (expressly rejecting the proposal for a differentiated bar and recommending instead that all applicants for bar admission be graduates of a law school)) cited in John O. Sonsteng, A Legal Education Renaissance: A Practical Approach for the TwentyFirst Century, William Mitchell College of Law Legal Studies Research Paper No. 89, Dec. 2007, revised Apr. 2, 2008 at 15 (hereafter "Sonsteng").

18 Alfred Zantzinger Reed, Training For The Public Profession Of The Law 238 (R.H. Helmholz \& Bernard D. Reams, Jr. eds., William S. Hein Co. 1986) (1921) (stating the need for the more highly trained lawyers to "undertake the task of making the law of the community better," and those less highly trained to administer "the law as it is") cited in Sonsteng.
} 
many located on well-respected college and university campuses, to cannibalize those beneath them in a race to the bottom. Faculty at such schools would have little or no time for research, would have weakened or no tenure protections and would likely never develop a sense that they are protected by academic freedom or have an important role in the shared governance of the institution.

Where would that lead? It would lead to the dissolution of the barrier between the university and the marketplace itself. That would mean a school that teaches more and more in response to the demands of that marketplace. Of course, to a certain extent that is inevitable and desirable. Twenty years ago few schools were offering courses related to bio-ethics whereas with the rise of biotech industries that area is now very popular. I think it is fair to say that on my own faculty I am more aggressive than most in pushing our school to be responsive to changes in the outside environment. But it is incumbent on universities to decide whether or not to adopt new ideas for teaching, research and other programming based on whether or not it truly advances human knowledge, not simply whether it helps the bottom line of the institution.

Tamanaha ignores the original motive for the "law as science" model installed at Harvard under the leadership of Christopher Columbus Langdell. It should be recalled that Langdell, the architect of the modern law school, left Wall Street for Harvard "in response to the corruption of the judiciary and the complicity of eminent lawyers in 
Boss Tweed's New York."19 Thus, the need to "segregate legal education from lawyers and the practice of law" was a central theme in Langdell's landmark efforts. ${ }^{20}$

The ability to strike such a balance between the university's commitment to objectivity and the pressures of the outside market place would be lost in an environment where schools were not just allowed but encouraged to engage solely in teaching. In fact, teaching would soon become merely training. At some point such institutions would cease to be graduate schools in any meaningful sense. ${ }^{21}$ Tamanaha contends that these types of schools enabled excluded groups to become lawyers before the ABA and university-based "elite" law schools created the modern tenure based law school (most recently in an interview, unsurprisingly, at the Cato Institute.) $)^{22}$

This viewpoint reminds me of those who advocate lowering the minimum wage and age of employment because child labor provides an entry into the workforce. That there were discriminatory barriers against entry of minorities, ethnic groups and women into law schools a century ago is true; but it does not follow that we have to 19 Sonsteng at 15.

${ }^{20}$ William R. Trail \& William D. Underwood, The Decline of Professional Legal Training and a Proposal for its Revitalization in Professional Law Schools, 48 Baylor L. Rev. 201, 206 (1996) cited in Sonsteng.

${ }^{21}$ This is not meant to denigrate the potential of genuine teaching colleges of law. There are numerous law schools that do not adopt uniformly the "research university" model, including my own. The key question is whether the principles of academic freedom including tenure and shared governance are at the heart of the institution. Only then do we have some guarantee that pedagogical choices are made with the benefit of independent thought. This process is analogous to the autonomy of the rule of law itself from the social and economic forces of the surrounding society. Tamanaha, however, is explicit in his call for "deletion" of ABA Standards 402-405 that mandate tenure, support research by faculty and create job security for faculty, a step he views as critical to solving the "fundamental problem" of the law school. This conclusion seems to contradict his earlier statement at the outset of the book that "academic freedom is critical to the academy and tenure protects academic freedom." A closer reading suggests that that statement was intended as a straw man.

22 Cato Institute Daily Podcast with Brian Tamanaha, Jan. 18, 2013 available at http://www.cato.org/multimedia/daily-podcast/failing-law-schools. 
destroy the quality and standards established over the last century in order to provide access to more potential lawyers. The proof of this lies in the presence today of law school classes that are half women and half men and with much greater racial, ethnic, ideological and methodological diversity than could have been imagined in the days of Kingsfield. ${ }^{23}$

Of course, these types of schools might be able to be run at lower cost because developing the human capital of an effective modern university is a complex, expensive and time-consuming enterprise. In fact, it is quite likely that such schools would soon advertise their lower cost in order to attract students. And inevitably the students who would be attracted to such schools would be those with fewer resources, from the very communities that we know today are already at a disadvantage. In other words, tearing up (or "deleting," to use the word Tamanaha uses) the standards built over the last century would encourage a new two tier system of legal education, one where minorities, immigrants, women and other groups with fewer resources and less successful backgrounds would be ghettoized. These individuals would be denied the opportunity to participate in the rich culture of a genuine university setting. We would be on the road back to the era of "separate but equal" which, of course, was anything but. ${ }^{24}$ Meanwhile the elite schools would stagnate, too, suffering both from growing homogeneity in their student bodies and over time their faculties but also in their

${ }^{23}$ Ironically, many of Tamanaha's fans are apparently out of work lawyers who think many law schools should be shut down in order to reduce the training of more competitors not to open the doors to a flood of willing competitors. However, the greatest irony, or perhaps tragedy, of Tamanaha's perspective is that his proposal would undermine the very academic culture that enabled him to produce his most important work on the rule of law itself.

${ }^{24}$ See discussion infra. 
ideologies and methodologies as they felt pressure to respond only to major corporate firms.

As I suggested at the outset, there is nothing I can think of now that law schools could have done in 2006 to warn aspiring lawyers about the crash of 2008. An argument that law schools "should have known" the good times would not last forever reminds me of the old saying that a broken clock is right, twice a day. There is zero chance that a large complicated bureaucracy, which the modern university has become, can turn on a dime in response to vague fears of a future calamity.

But if law schools are worth their salt as academic institutions, and I believe their place in the university setting must remain secure, they should be able to learn about the nature of their profession and implement change as needed to respond to the demands of that profession.

The simplistic call by Tamanaha for a two tier, Big U/community college style system, however, strikes me as deeply problematic. Many law schools already rely heavily on adjunct teaching by local lawyers and judges that often brings valuable real world experience on to the campus but can also lead to concerns about teaching style and grading patterns. Despite what the academic critics say, there is an art to teaching well and it is not an art that all possess or can easily learn, particularly after a 60-hour week at the firm. There is certainly no way that most adjunct style teachers can engage in research or theoretical work which is the real value added, that should be added, by having tenure track faculty in the classroom. 
This highlights, as well, the pressure on law schools to substitute for early training by law firms. That requires expanded clinical and experiential learning programs. Most law schools have such programs and have indeed bulked those up in response to those pressures. But those programs are by their nature expensive and require very small faculty-student ratios; precisely the opposite direction that most reformers think schools ought to go. Thus, the law school becomes a horse with two heads.

This is not to say, of course, that there are not and should not be consideration of alternatives to the way the law school works today. In fact, law schools already attempt to reduce costs and improve exposure of students to new ideas by establishing clinical and experiential learning opportunities, and are experimenting with alternatives to the three-year degree. ${ }^{25}$ It is fair to say that today the law school has done an excellent job of incorporating the principles of differentiation articulated by Reed in 1921 within the current institutional framework. The critical point is that today the law school remains grounded by the principles of academic freedom and tenure because it is the tenure track faculty who have a central role in a system of governance shared with the school's administration and the administration and trustees of the university in which the law school is housed.

What then does Tamanaha say caused our law schools to fail?

\footnotetext{
${ }^{25}$ It must be recalled, of course, that clinical programs are resource intensive and thus add to the cost per capita. The latest proposal comes from two top tier law school deans and has led to widespread debate. See Daniel B. Rodriguez and Samuel Estreicher, "Make Law Schools Earn a Third Year" N.Y. Times, Jan. 17, 2013 at A27.
} 


\section{What was the law schools' original sin?}

While the book covers a range of important issues, the crux of the argument can be found in a graph that makes up Figure 6.1 in the book. If a crime is to be found it would seem that this graph is Tamanaha's smoking gun. Tamanaha appears to have derived the chart himself from data provided by the LSAC and the ABA. (I use here only LSAC data, which varies slightly from the ABA numbers.) While Tamanaha claims that law schools "created a systemic mismatch" (emphasis added) between graduates and jobs, it is not clear that is true from the data that underlies his graphic depiction of the crime. And if Tamanaha cannot show this mismatch then a huge hole opens up in his claim that law schools are failing because the revenue based motivation for that failure dissipates. (I find the 1990s data he presents even weaker and certainly less germane so I am skipping over that here.)

I believe that it has been my emphasis in the recent blog war $^{26}$ on the correlation between applicants and jobs relative to the wider economic problem that has created such a stir. This perspective suggests a different explanation for the unemployment of many lawyers. It may or may not be right, although I think it is, but what the "scam" crowd seems to fear the most, and what they have gone out of their way to prevent through mob behavior on the web, is even the suggestion of a credible alternative theory.

${ }^{26}$ See debates at web pages The Faculty Lounge and TaxProf. 
According to the LSAC, for example, law school applications increased $9.5 \%$ in 2003 but admitted students (called "Admits") only went up 0.6\%.27 No opportunistic yield management there. When applications increased only $1.1 \%$ the following year Admits dropped $1.6 \%$. While the next four years saw a steady drop each year in applicants from 95,000 in 2005 to 83,400 in 2008, Admits remained flat or slightly negative.

This might suggest opportunistic yield management in order to avoid cutbacks as Tamanaha concludes with alacrity. But consider why the number of applicants was dropping. Was it because the economy was weak and students were reluctant to take out large loans? In fact, the economy was booming as what we now know, in hindsight, as a credit bubble looked to everyone, outside of a few skeptical hedge funds, ${ }^{28}$ like a robust global economy. Any member of a board of trustees who heard a proposal from a law school dean in 2006 to reduce admissions likely would have asked for that dean's resignation!

As reality set in, the actual numbers of applicants nationwide, counterintuitively, increased in 2009 and 2010 as students looked to hide out in law school, which even Tamanaha admits. The jobs that were available due to a real estate induced bubble in 2007 had gone up in smoke and there was no place to go but graduate school. After hitting a low of 83,400 in 2008 applicants hit a five-year high of 87,900 in 2010.

\footnotetext{
${ }^{27}$ Law School Admissions Council, LSAC Volume Summary available at http:// www.lsac.org/lsacresources/data/lsac-volume-summary.asp.

${ }^{28}$ To get a flavor for how isolated and rare such predictions were at the time see Michael Lewis, The Big Short: Inside the Doomsday Machine (2010).
} 
In these two years, there does appear to have been a disconnection between the increase in applicants relative to the increase in admitted students. But it was small. There was an absolute 1.3\% surplus of Admits above applicants in 2009 and 2.0\% in 2010. The number of first year enrolled students increased in 2009 from the previous year by some 2,200 students across 200 law schools nationwide, which represents an increase of only eleven (11) per school. The next year the number jumps by fewer students, only 900, an additional 4.5 students per school. While Tamanaha claims a sinister motive behind the decision of schools to bulk up when they can take advantage, he misses the fact that they grow only slowly but cut back harshly. The next year, enrollment dropped by 3,800 students, or 19 per school. And, indeed, consistent with past patterns those numbers have continued to drop independent, I would suggest, of the change in disclosures of job statistics by law schools, which only occurred in a systematic way in late 2012 when the ABA issued new guidelines.

Tamanaha provides no breakdown here of the data among schools, even between various large categories of schools such as big or small, public or private, nor is there any discussion of the complexities of the yield management process. There is no indication of the impact of new law schools such as UC Irvine or UMass Dartmouth that have come on the scene recently. Because the numbers are small it is possible that completely appropriate individual decisions at a small number of schools explain the disconnection in those two years. It may have happened at large public schools facing budget crises. It may have happened at the newer "for profit" schools. Nor is there any 
comparative analysis here. What was happening, for example, at other professional schools during this same period?

As for possible alternative explanations for generalized behavior across the law school environment, there would seem to be several possibilities. After many decades of feeling pressure to widen enrollment in order to meet labor market demand and help improve diversity in the profession it is a tough decision for an institution to block the schoolhouse door. After all law schools could very easily solve the so-called "oversupply" 29 problem by returning to the days of The Paper Chase, where women, blacks and Hispanics were a "discrete and insular minority" among law students. ${ }^{30}$ Tamanaha seems to yearn for the days in the late $19^{\text {th }}$ and early $20^{\text {th }}$ century when such diploma mills were, indeed, the only place that immigrants could receive legal training. He decries the role of the "elite schools" of that period in imposing the early stages of the modern research oriented culture of the law school. He fails to see the important gains that approach made for the universities, the rule of law and, over time, access to the unique value of such an environment for all of those previously excluded groups.

${ }^{29}$ I place "oversupply" in scare quotes because while certainly the number of jobs provided by the market itself has shrunk, there is a reasonable argument to be made that the need for legal services remains acute. My proposal for a combined debt relief and post-law school training program is aimed at dealing with both the job situation as well as that need. See "Lawyers for America: A modest proposal," available at http://stephen-diamond.com/beyond-the-scam-debate-about-law-schools-lawyers-foramerica-a-modest-proposal/.

30 United States v. Carolene Products Company, 304 U.S. 144 (1938) Footnote 4 (“Nor need we inquire whether similar considerations enter into the review of statutes directed at particular religious ... or national ... or racial minorities ...: whether prejudice against discrete and insular minorities may be a special condition, which tends seriously to curtail the operation of those political processes ordinarily to be relied upon to protect minorities, and which may call for a correspondingly more searching judicial inquiry." (Italics added)) 
It is the modern university, for example, that provided the training and research that led, in part, to the overturning of Plessey v. Ferguson in Brown v. Board of Education in 1954. Thus, it was the social psychologist Dr. Kenneth Clark who introduced Martin Luther King when he gave a speech on the importance of ending segregation in the school system in 1956. King singled out for praise in that speech the NAACP which housed the key lawyers in the litigation, including Thurgood Marshall, and the "noble work" of the team of social psychologists led by Dr. Clark "who came to see, through long study, that segregation does something to the personality. That is why the Supreme Court said that segregation generates a sense and feeling of inferiority within children that distorts their personality." 31

\section{Where is the counter-factual?}

Two other factors were at play in the volatility of enrollment figures in the last decade, including an aggressive macroeconomic policy committed to low interest rates, certainly well outside the control or influence of law school admissions officers, which resulted in the availability of low interest loans, and a reasonable sense among many students that perhaps the crisis was not as bad as it seemed, or at least would not be as prolonged. Indeed, two prior economic meltdowns, including the dot.com crash of 2000 and the real estate/LBO crash of the early 1990s were less severe and turned around reasonably quickly. Only a thoughtful counter-factual analysis could answer

\footnotetext{
${ }^{31}$ Dr. Martin Luther King, "Desegregation and the Future," Address Delivered at the Annual Luncheon of the National Committee for Rural Schools, Dec. 15, 1956, available at http:/ / mlkkpp01.stanford.edu/primarydocuments/Vol3/15-Dec-1956_DesegregationAndTheFuture.pdf
} 
the question, what would have happened in the absence of the unprecedented volatility of the last five years?

I have been studying the capital markets, as well as the phenomenon of financialization and fictitious capital, for over a decade. In the late 1990s I was a cofounder of a small group of academics and activists called "Meltdown" which studied the growing disconnect between financial instruments like mortgage loan-based derivatives and the underlying growth of the real economy. I gave a talk on the crisis in the fall of 2008 where I backed the Bush proposed infusion of cash into the banking system and suggested dire consequences if the state did not step in with unprecedented policy measures. ${ }^{32}$ Despite that background and, dare I say it, perhaps a perverse desire to see what might happen if my research ideas about the problems of the capital markets played out in the real world, you could have knocked me over with a feather then if you told me the entire world would be threatened by the crisis with countries like Greece going up in flames.

Does the law school "truther" crowd really want to claim that admissions officers or law school deans (perhaps too few of whom have business law backgrounds) should have called a "top" in the world economy and cut law school class sizes by 15\%? Did Campos or Tamanaha issue early warning calls? Campos himself claims that the earliest warning his side in the debate gave was that Summer 2010 blog post on

\footnotetext{
32 Anatomy of a financial meltdown, September 30, 2008, Santa Clara University School of Law, slides available at http:/ / papers.ssrn.com/sol3/papers.cfm?abstract_id=1276131.
} 
Balkinization. ${ }^{33}$ That hardly qualifies as prescient. By then, as Michael Lewis' Spring 2010 book had already explained, the shorts had all covered and retired to Ravello. ${ }^{34}$

In any case, it was at that point that law schools started admitting far fewer students. ${ }^{35}$ Was it Tamanaha or the law schools themselves that realized that the problems in the economy were not going away? Only careful econometric analysis or survey research of faculty and university decision-making can settle that causality question. Tamanaha chose not to do that work but to rely instead on broad-brush statistical material and anecdotal information that allows us, in fact, to come to several possible explanations for the situation we face.

\section{Beware hindsight bias}

One must be careful in other words, of the power of hindsight bias. This situation is similar to the problem that arises when courts are asked to assess the impact of corporate risk management programs after a crisis engulfs a company. It is challenging to ask what the world looked like at the time the decisions were made. This is not to excuse the possibility of fraud, which sadly has hit some law schools. But it cautions against painting with a broad brush. Careful work with the data of individual law schools might show other possibilities, but my intuition says that that would lead to a non-result.

\footnotetext{
33 Tamanaha, supra note 2.

34 Lewis, supra note 29.

35 LSAC figures indicate a 7.7\% drop in Admits in the fall of 2011. Those students began the application process in the fall of 2010. Granted, the drop in applicants was higher, $10.7 \%$, which suggests some defensive enrollment efforts by law schools.
} 
For example, the collective number of applications to law schools also increased in 2009 and 2010 and at a higher rate than the number of applicants, admitted students or enrolled students. That is a reflection of law school applicants' collective choice to apply to more law schools to increase the chances of admission somewhere in a more competitive environment. It is not easy to see how individual admissions teams can be blamed for the effect that had on increased enrollment. Some blame that two-year blip up on allegedly false or misleading jobs data on law school websites. But was the data any less misleading in 2005, 2006 and 2007 when the number of applications declined?

When applications dropped off in 2011, as they did again in the fall of 2012 and will in the fall of 2013, so did admissions and enrollments. Schools responded to the rational decisions of college graduates to look to other career choices. I certainly know that at my law school there were several opportunities where the school could have increased class size substantially in response to banging on that door. Tamanaha's charge of widespread yield management abuse across the law school world seems unpersuasive.

\section{Read Liz, Listen to Sean Parker}

In the Albany Law School case where the New York Supreme Court recently dismissed another disclosure action by a disappointed student they made the important point that students bear some level of responsibility for engaging in due diligence in order to determine whether law school is the right choice. ${ }^{36}$ The writer Elizabeth

36 Austin v. Albany Law Sch. of Union Univ., 2013 NY Slip Op. 2300 (Jan. 3, 2013) available at http:// www.nylj.com/nylawyer/adgifs/decisions/010713platkin.htm. ("The Court is not persuaded 
Wurtzel is likely not the only person to ever to law school on a "lark," as she put it, but in a widely discussed essay she was brutally honest recently about the potential downside of that approach even if one casually enrolls in a top tier school. ${ }^{37}$

My own view is that college graduates need to take a page out of The Social Network when considering an application to law school: as simplistic as it may sound, imagine you personally are a potential startup and you have a chance to invest a significant amount of time and money in adding to its human capital. Are you ready to drop out of Harvard and move to Palo Alto as Sean Parker encouraged Mark Zuckerberg to do, at least in the film version of Zuckerberg's experience? There are risks and rewards. The law school, its faculty, and its alums may all be able to add useful information to your analysis. In the end, though, it is your decision. Will you be better off than you would be without a JD? In many cases, perhaps most, I think you will be. A JD is a powerful degree to have in our kind of society and, despite the current mismatch in the job market, a relatively rare one. ${ }^{38}$

that GBL 349 [one of the statutes in question] requires an institution such as ALS to ascertain these types of individualized needs and guarantee that its published employment statistics suit each prospective or current student. Nor would it be reasonable for students to read all of their hopes and aspirations concerning the practice of law into the unadorned employment rate published by ALS. Rather, insofar as plaintiffs' decision to attend ALS turned on an employment rate limited to positions for which a JD is required or preferred, it was incumbent upon plaintiffs to ascertain whether ALS's published data fit their particular assumptions and met their specific needs.")

${ }^{37}$ Elizabeth Wurtzel, “Elizabeth Wurtzel Confronts Her One-Night Stand of a Life" New York Magazine, Jan. 6, 2013 available at http:/ / nymag.com/thecut/2013/01/elizabeth-wurtzel-on-self-help.html.

38 In the era that Tamanaha pines for, the early $20^{\text {th }}$ century, there were 150 law schools and 27,000 law students. J. Gordon Hylton, The Impact of the 1921 Carnegie Report on Legal Education (Power Point presentation). The U.S. population at the time was 106 million. In 2008 there were $200 \mathrm{ABA}$ accredited law schools and 143,000 law students. The population today is 315 million. We can debate whether the complexity of today's society calls for such an increase in the density of individuals choosing to study law but can Tamanaha credibly claim that such an increase in density is evidence of a decline in access and diversity due to increased costs? 


\section{A return to the rule of law}

This leaves us with a final problem inherent in the approach of Tamanaha, one that returns us to the rule of law debate. As suggested above, the secure place of the law school as an academic field is an "unqualified human good." The twin pillars of tenure and academic freedom secure that place for our field. This has a larger impact, as law schools provide a social or public good of the kind suggested by the New York Appellate Division in the New York Law School case. The relative autonomy that academic freedom and tenure establish for law school faculty signals the autonomy of the law itself. The value of this autonomy may be found in as simple an example as explaining to law students why they should rise to attention when a judge walks into her courtroom. Or its importance may be evident when a professor must confront something as sensitive as teaching Heller in the wake of Newtown.

And while respect for this approach may seem to be a return to an outdated formalism, we all know how vital this cultural autonomy of the faculty is to the project itself. Yes, there is a danger of abuse of the privilege, but as Tamanaha admits there are sources of "leverage" that deans have to deal with those abuses. There is some evidence that Tamanaha has reminded deans of that leverage and that is likely a good thing.

Our thinking must be far more creative and nuanced than a simplistic call for a return to the two tier law schools found in the era of Adolf Reed. It is entirely possible to create structural solutions, to alter the curriculum, to increase diversity within the faculty (with respect to both ideology (something that gets too little attention) and with respect to identity), within a system that respects protection for faculty to pursue ideas 
in teaching and research freely. Many schools are engaging in reform. Stanford recently shifted to a quarter system to allow easier collaboration with the rest of the university. This also opens up the possibility of shorter courses that can be targeted to particular needs. From my own experience in advising students in our JD/MBA program the potential advantages of that kind of shift are significant.

Law schools need to be closer to the profession as well, particularly in settings outside the traditional chats with hiring partners at major firms. Deans must bring back to the faculty their experiences in the field to help fuel the internal discussions about innovation. This requires more robust use of the system of shared governance that should steer colleges and universities.

There are two macro trends impacting law schools today that schools must confront. First is the one that I have focused on in the recent debate, the deep financial and economic crisis. A second longer term but less visible trend, however, is the technological and institutional change underway in legal practice. ${ }^{39}$ Firms seem finally to be getting smarter about hiring, after suffering traumatic downturns twice in the last decade. The era when BigLaw firms could generate huge leverage hiring lots of first year associates, most of whom would quickly be burned out or turned off by the drudgery of some aspects of corporate practice, may finally be over. Wurtzel caught the reality of this drudgery quite well in her New York magazine essay:

39 Bernard A. Burk and David McGowan, “Big But Brittle: Economic Perspectives on the Future of the Law Firm in the New Economy," 2011 Colum. Bus. L. Rev. 1 (2011). 
$[\mathrm{M}]$ ost people who think they are practicing law are actually making binders, and my guess is that most people who think they are doing whatever important thing they are doing are making binders. The binders from law firms go to a locker in a warehouse in a parking lot in an office park off an exit of a turnpike off a highway off an interstate in New Jersey, never to be looked at again. No one ever read them in the first place. But some client was billed for the hourly work. ${ }^{40}$

Tamanaha complains about walking through the hallways of his first law school only to find no one at home. Perhaps they were, in fact, malingering. But he should try finding a business school faculty member in their office. And I can assure him that they are not malingering. If they are not in the classroom or conferring with students in office hours they are meeting with business leaders and conducting research. A similar situation can be found in the sciences. Faculty may not be in their offices outside of office hours but they are not malingering either; they are in their labs.

That suggests to me two other ways to think about the problems we face. Both business schools and the sciences offer some interesting alternatives. The business schools do a very good job of staying in touch with their major external constituencies and not just at the administration level. Faculty are involved in a variety of projects with those groups on a regular basis. While there have been some important critiques of this revolving door it has important advantages, too.

Business schools also seem to be able to make the kinds of revisions to internal structure needed periodically in their field. Because business itself must be nimble to survive so too must the business schools. But it is not enough for law schools to blame

\footnotetext{
${ }^{40}$ Wurtzel, supra note 38 . It should be said, however, that Wurtzel says she loved being in law school, but then again she didn't really go to law school, she went to Yale. And although she had a terrible 2012, her essay ends on a positive note.
} 
their sluggishness on the stodgy behavior of law firms. And certainly today no one thinks that law firms can remain content with the old way of doing business.

The sciences offer another model: research groups. A senior scientist directs a lab made up of his graduate students and a number of permanent academic staff. The students get real exposure on a regular basis to ongoing research projects. This is a vital supplement to what is going on in the classroom. Some law schools have already taken this approach on board. It is easier to do at major research universities, of course, where specialists in IP or bio-ethics can join hard science teams. While at top tier schools joint authorship of research papers with students is occasionally found and research assistants exist at many levels within the law school world, a lab or research group approach would be more collaborative and impart important skills to students.

\section{Our Social Contract}

Neither of these approaches in the sciences or the business school environment is inconsistent with tenure and academic freedom. In fact, I would argue that those rights lay the groundwork for the success of these models. They provide the fundamental barrier required between the academy and the pressures of the wider world. While the academy must be responsive to that external environment, it must not lose its autonomy. Only that independence insures that genuine freedom of thought can develop because the university retains some distance from the pressures that face businesses, courts, agencies, non-profits and other organizations. 
The university has entered into a social contract of sorts with society as a whole: academics accept lower salaries than can typically be found in the private sector in return for a commitment to train the next generation of our society while attempting, as well, to generate ideas about, and solutions to, important and even not so important problems.

It is true that this endeavor, at least the attempt to find useful ideas and solutions, is a hit and miss affair. It is true that only a handful of academics will ever produce work that secures a MacArthur Genius award or a Nobel Prize. But there is a reason that American universities are the envy of the world. And there is a reason American law schools have assumed a leading role in spreading concepts like democracy, human rights and the rule of law in the post Cold War era.

While there are certain aspects of Tamanaha's critique of this effort that ring true (see his "Dark Side" article, for example ${ }^{41}$ ), it is also the case that the United States has long protected and nurtured, in ways that other countries deeply envy, what we call "intellectual capital." Our universities are a vital part of an ecosystem that allows thousands of smart creative people the time and space to come up with new ideas, new solutions, and new problems. The legal culture as well as academic culture is a vital source of support for this effort.

Thus, when I hear the kinds of reactions among law students that one hears today about the law school environment, it is reasonable to become concerned that a

${ }^{41}$ Brian Z. Tamanaha, “The Dark Side of the Relationship Between the Rule of Law and Liberalism," 3 NYU Journal of Law and Liberty 516 (2008). 
new form of "anti-intellectualism" is taking hold in American culture. ${ }^{42}$ I can understand the anger and anxiety induced by the ongoing economic meltdown but it is precisely at this point that we must resist the pressure to sacrifice the place of the university in our culture and as well the place of the law school in the university.

42 Richard Hofstadter, Anti-intellectualism in American Life (1963). 